\title{
The Brazilian sanitation sector's response to COVID-19
}

\author{
Morganna Werneck Capodeferro' 2 \\ Juliana Jerônimo Smiderle ${ }^{13}$ \\ 1 Fundação Getulio Vargas / Center for Regulatory and Infrastructure Studies, Rio de Janeiro / RJ - Brazil \\ 2 Universidade Federal do Rio de Janeiro / Civil Engineering Program, Rio de Janeiro / RJ - Brazil \\ 3 Universidade Federal do Rio de Janeiro / Environmental Engineering Program, Rio de Janeiro / RJ - Brazil
}

The COVID-19 pandemic has evidenced the essentiality of water more prominently. Service providers were responsible for maintaining drinking water supply to the population to maintain good hygiene habits and control the spread of the virus. However, the challenge for providers was guaranteeing the service would not be affected, either by employees falling ill or by users unable to pay for the service provision. Public administration adopted several measures to respond in the short term to this challenge. The actions most frequently observed were the restriction of in-person services, payment exemption for vulnerable users, and suspension of procedures against non-payment. The measures may have unbalanced the accounts of the service providers, leaving them in a situation of instability that, in principle, should be sustained until the end of the pandemic, when the regulators will conduct the process to re-establishing the financial balance. The regulators are and will be the main actors in minimizing the impacts on providers and in mediating future negotiations. This article provides recommendations to regulators on how to address the imbalances caused by the pandemic in future processes. Regulators will have to issue clear guidelines regarding the procedures that providers will adopt to rebalance their accounts. Consideration should be given at this time to making contractual targets more flexible.

Keywords: COVID-19; water and sanitation; economic and financial imbalance; regulation.

\section{A resposta do setor de saneamento no Brasil à COVID-19}

A essencialidade da água à vida talvez tenha ficado ainda mais evidente com a pandemia da COVID-19. Aos prestadores dos serviços de saneamento foi atribuída a responsabilidade de garantir à população a manutenção do abastecimento de água potável, fornecendo meios para que ela pudesse preservar os hábitos de higiene e controlar a propagação do vírus. No entanto, como se poderia garantir que a prestação do serviço não fosse afetada, seja pelo acometimento dos funcionários, seja pela reduzida capacidade de pagamento dos usuários? Este foi o desafio enfrentado pelos prestadores. Diversas foram as medidas adotadas pela Administração Pública para responder no curto prazo a esse desafio, tais como: restrição ao atendimento presencial nas unidades, isenção tarifária aos usuários da tarifa social e suspensão do corte por inadimplência. Contudo todas estas medidas podem desequilibrar as contas dos prestadores de serviço, deixando-os em uma situação de instabilidade que, a princípio, deverá ser sustentada até o fim da pandemia, quando os processos de reequilíbrio econômico-financeiro serão conduzidos pelos reguladores. Estes são e continuarão sendo os principais atores na minimização dos impactos que incidiram sobre os prestadores e na mediação das negociações futuras. Este artigo traz recomendações aos reguladores sobre como tratar os desequilíbrios causados pela pandemia nos futuros processos. Caberá aos reguladores emitir diretrizes claras com relação ao procedimento a ser adotado pelos prestadores, para que possam pleitear o reequilíbrio de suas contas. Deve-se cogitar neste momento a flexibilização das metas contratuais.

Palavras-chave: COVID-19; água e saneamento; desequilíbrio econômico-financeiro; regulação. 


\section{La respuesta del sector de saneamiento en Brasil a la COVID-19}

Talvez, la esencialidad del agua para la vida se ha hecho aún más evidente con la pandemia de COVID-19. Los proveedores de servicios de saneamiento tuvieron la responsabilidad de mantener el suministro de agua potable para proporcionarle a la población los medios para mantener sus hábitos de higiene y controlar la propagación del virus. Pero, ¿cómo podría garantizarse que la prestación del servicio no se vería afectada, sea por la disminución de empleados o la capacidad de pago reducida de los usuarios? Este fue el desafío planteado a los proveedores. La Administración Pública tomó varias medidas para responder rápidamente a este desafío. Las iniciativas más adoptadas fueron la restricción del servicio presencial, la exención de tarifas para los usuarios vulnerables socioeconómicamente y la suspensión del corte por incumplimiento. El hecho es que todas las medidas pueden desequilibrar las cuentas de los proveedores de servicios, dejándolos en una situación de inestabilidad que, en principio, debería mantenerse hasta el final de la pandemia, cuando los reguladores llevarán a cabo los procesos de reequilibrio económico y financiero. Los reguladores son y serán los principales actores para minimizar los impactos en los proveedores y mediar en las negociaciones futuras. Este artículo proporciona recomendaciones a los reguladores sobre cómo abordar los desequilibrios causados por la pandemia en procesos futuros. Competirá a los reguladores emitir pautas claras con respecto al procedimiento que adoptarán los proveedores para que puedan reclamar el reequilibrio de sus cuentas. En este momento, se debe considerar la flexibilización de los objetivos contractuales.

Palabras clave: COVID-19; agua y saneamiento; desequilibrio económico y financiero; regulación.

\section{INTRODUCTION}

The COVID-19 pandemic has brought challenges never faced by the Public Administration, notably the maintenance of essential services provisions, such as electricity, telecommunications, and drinking water supply and sewage collection. Since the beginning of the pandemic, the World Health Organization (WHO) has published technical guidelines for countries to face the new disease. One of the main guidelines - which is recommended in all situations to reduce the speed of transmission of the virus - refers to the maintenance of good hygiene habits; among them, frequently washing hands with soap and water (WHO, 2020). It sounds simple and basic, but unfortunately, it is not. According to the most recent data from the United Nations Children's Fund and the World Health Organization (UNICEF \& WHO, 2019), 40\% of the world's population (3 billion people) did not have basic handwashing facilities in their homes in 2017. In the particular case of Brazil, 33 million people do not receive piped water in their homes (Ministry of Regional Development [MDR], 2018).

A recent article published by Wu et al. (2020) suggests the possible presence of the new coronavirus in patients' excrements for almost five weeks after respiratory tests were negative. Yeo, Kaushal, and Yeo (2020) enunciated this hypothesis, since SARS-CoV and MERS-CoV, two already known types of coronavirus, were identified in sewage under conditions that facilitated feco-oral transmission. These same authors pointed out that the possibility of this type of transmission of COVID-19 has severe implications, especially in areas lacking sanitation. This is the situation of 4.2 billion people in the world (UNICEF \& WHO, 2019) and of 95 million Brazilians who are deprived of access to the sewage collection network (MDR, 2018). In Brazil, less than half of the collected sewage is treated (MDR, 2018).

To maintain good hygiene habits, WHO recommends ensuring a safe water supply for the population. But how can sanitation sector players guarantee the service will not be affected, either 
by employees falling ill or by users that cannot pay for the service provision? We must also consider the safety of the employees that will continue to work to maintain the service provision. What are the short, medium, and long-term impacts on the different stakeholders due to the actions undertaken to sustain the service provision? How should the Public Administration respond to minimize these negative impacts? These are the questions that this article seeks to address for the Brazilian context.

First, this article describes the Brazilian sanitation sector; then, it outlines the immediate responses given by the Public Administration in the face of the challenge imposed by the pandemic. Our focus is on the actions that affected the 26 State Companies (SCs). We analyze the impacts that result from the identified actions according to the different players in the sector, i.e., service providers, users, and regulators. Based on this analysis, we formulated recommendations to tackle negative impacts for the Public Administration.

\section{WATER SUPPLY AND SANITATION SERVICE PROVISION IN BRAZIL}

Considering the actions to prevent COVID-19 and their respective impacts on the Brazilian water supply and sanitation (WSS) service providers, we will first present the structure of the sanitation sector in the country. According to the Federal Supreme Court, municipalities are responsible for the sanitation services in Brazil, and as such they may provide sanitation services directly or delegate them to third parties. Direct provision occurs in $22 \%$ of the municipalities (MDR, 2018), and among those that delegate service provision, $96 \%$ are served by SCs. The others have services provided by private initiative. Figure 1 shows the percentage of the population served by each type of service provider.

\section{FIGURE 1 PERCENTAGE OF THE POPULATION SERVED BY EACH TYPE OF SERVICE PROVIDER}

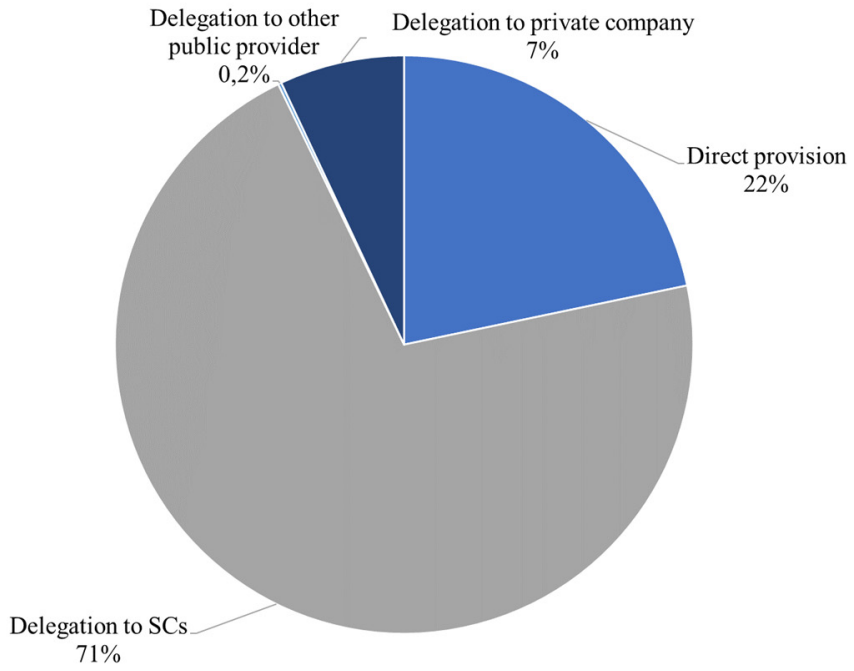

Source: MDR (2018). 
The provision of sanitation services was structured and historically concentrated around SCs (Smiderle, Capodeferro, Fernandes, Gonçalves, \& Dutra, 2020), most of which are public companies. Of the $26 \mathrm{SCs}$ that currently exist in the country, only one is privately managed. Hence, there is substantial state involvement in the sector, although municipalities are responsible for the service.

The sector had been structured through SCs because of the opportunity this arrangement offered to make the service economically viable. As SCs operate in a group of municipalities in the same state, they adopt a single tariff structure - or with few variations -, which leads to an arrangement of cross-subsidy, whether between municipalities or between different classes of consumers. In general, the tariff structure is divided into user categories (residential, commercial, industrial, and public) and consumption blocks. The subsidy between consumer classes usually occurs between non-residential and residential users; the latter pay lower tariffs compared to commercial, industrial, and public categories.

\section{IMMEDIATE RESPONSES FROM THE PUBLIC ADMINISTRATION}

Since the first case of COVID-19 was diagnosed in the country, many Brazilian states decreed social distancing measures, or quarantine, and established commerce shutdown and the paralysis of non-essential services. These measures themselves have a strong impact on economic activities and unemployment levels.

In this context, service providers faced the challenge of maintaining the drinking water supply, which is essential for disease prevention, to a population with a low capacity to pay for the service. Immediately, the sector's players (municipalities, service providers and regulators) created a series of actions aimed at protecting both utilities' employees and users, especially the most financially vulnerable.

This article investigates the actions that SCs adopted to comply with the decisions of their respective state governments and regulators. Among the actions analyzed, we highlight the following: (i) change in the method of billing; (ii) restriction of presential service; (iii) postponement of tariff adjustments; (iv) payment easing of water and sewage tariffs; (v) tariff exemption for vulnerable users; and (vi) suspension of procedures against non-payment.

Concerning employee protection, we have identified the adoption of measures aimed at reducing employee exposure and, consequently, users themselves. Some companies determined that the billing should consider average values of historical consumption to replace the reading of hydrometers, such as the Sanitation Company of the Federal District (Caesb) - through ADASA Resolution n. 03 (Resolução ADASA n. 03, 2020) -, the Sanitation Company of Minas Gerais (Copasa, 2020a) and the Sanitation Company of Rio Grande do Sul (Corsan, 2020). An alternative measure, created by Copasa, was the possibility for the user himself to read his hydrometer and inform the company. In this case, the bills continue to be issued based on the hydrometric consumption and not on the average historical consumption (Copasa, 2020b). Most companies have suspended or restricted their presential services, making virtual channels available for their customers.

Regarding the measures aimed at protecting users, the postponement of tariff adjustments was determined in order not to overcharge tariffs in times of economic slowdown. This measure 
was adopted in the state of Paraná, by the regulatory agency, which froze all regulated service tariffs (Regulatory Agency of Paraná State [Agepar], 2020), as well as in the state of Sergipe, by the Government of Sergipe State (2020), and in the Federal District, by Resolution ADASA n. 03 (Resolução ADASA n. 03, 2020).

Several measures have been taken to facilitate water and sewage tariffs payment. The deadline increase for paying the tariff was one of the most adopted actions. It was announced, for example, by Copasa (2020a) and the Sanitation Company of Paraná State (Sanepar). In the case of Paraná State, Sanepar postponed tariff payments for 90 days for users who pay a social tariff (Sanepar, 2020).

Other payment options include the possibility of installments, as was the case of the debt renegotiation campaign conducted by the Sanitation Company of Rio Grande do Norte State (Caern, 2020). Some state companies decided to suspend the collection of interest and fines resulting from the delay in payment. Copasa adopted such measure for users who fall under the social tariff (Copasa, 2020a), while the Sanitation Company of Amazonas State (Cosama) adopted it to users in general (Government of Amazonas State, 2020).

Several companies granted the tariff exemption to the residential social category, among them the Sanitation Company of Espírito Santo State (Cesan, 2020), the Sanitation Company of São Paulo State (Sabesp) (Deliberação ARSESP n. 979, 2020), and the Sanitation Company of Rio de Janeiro State (CEDAE, 2020). CEDAE complied with State Decree n. 46,990 (Decreto Estadual n. 46,990, 2020), which allowed the concession of tariff exemption for users included in the social tariff benefit and small commerce categories. Another measure of protection for financially vulnerable users that was adopted was the suspension of procedures against non-payment. The following state governments enacted such measures: Goiás State (Government of Goiás State, 2020), Tocantins State (Tocantins State Sanitation Agency, 2020), Santa Catarina State (Government of Santa Catarina State, 2020) and Rondônia State (Rondônia State Public Services Regulatory Agency [AGERO], 2020).

Figure 2 shows the result of the survey on protective measures adopted by SCs in response to the pandemic. As the text describes, these measures may have been determined either by the service provider itself or by state governments or regulators. For the protection of employees, we highlight the restriction to presential services as a measure adopted by the largest number of companies (88\%). For the protection of users, the suspension procedures against non-payment were adopted by $88 \%$ of state companies - this is a crucial measure to ensure the maintenance of drinking water supply to every user. 


\section{FIGURE 2 ADOPTION AMONG THE 26 SCS OF EACH OF THE MEASURES FOR MAINTAINING SERVICE} PROVISION DURING THE PANDEMIC

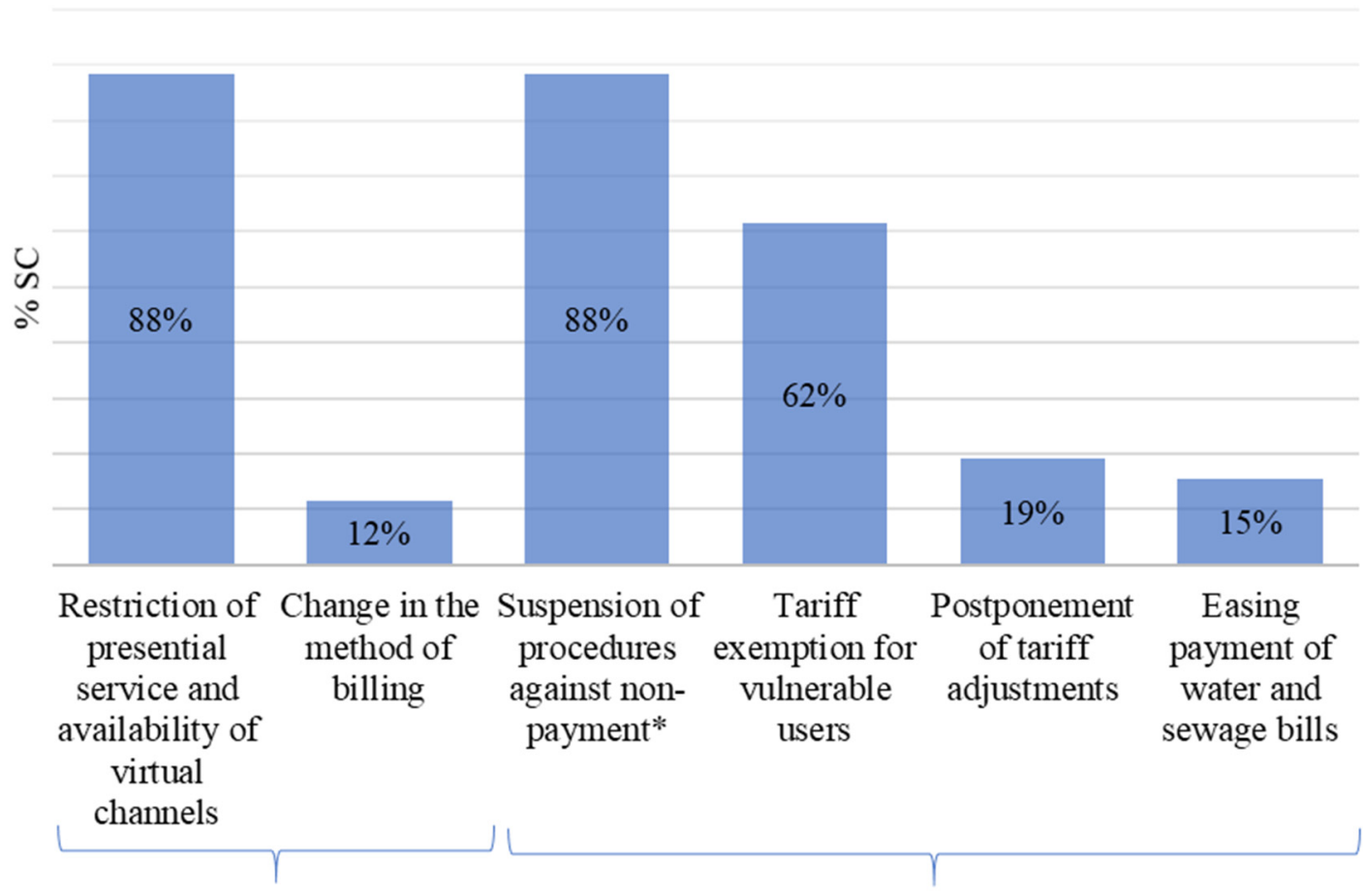

Measures for employee protection

Measures for users protection

\footnotetext{
* In four states (Minas Gerais, Bahia, Paraíba, and São Paulo), the procedures against non-payment was suspended only for users included in the social tariff benefit. Other companies applied this measure to all users.

Source: Elaborated by the authors.
}

We have restricted this analysis to SCs because they represent the states and they serve $70 \%$ of the Brazilian municipalities (MDR, 2018). However, these protective measures were also adopted by other service providers, such as private companies and municipal water and sewage companies (SAAEs). For example, private companies and the SAAEs regulated by the Regulatory Agency for Sanitation Services of the Piracicaba, Capivari and Jundiaí River Basins (ARES-PCJ), by a decision of the agency itself (Resolução ARES-PCJ n. 345, 2020); the private concessionaire Saneaqua Mairinque S/A, by a decision of the Sanitation and Energy Regulatory Agency of the State of São Paulo (Deliberação ARSESP n. 978, 2020); and the private company Iguá Saneamento (2020), which provides service in several locations, by a determination of the company itself.

Referring to how the sanitation sector has responded to the challenge of the pandemic internationally, we note a certain degree of alignment with the measures adopted in Brazil. Many of the actions aimed at protecting users meet the guidelines of the UK Water and Sewage Services Regulator, Office of Water (Ofwat). Ofwat is considered an international benchmark in regulation. It has a rich, long, and reliable performance in the sanitation sector, due to the English pioneerism in the privatization of service provision in the '70s (NH Consulting and Planning, 1995). When facing 
the pandemic, Ofwat required companies to provide support to vulnerable users, suggesting that they consider reducing the financial burden on these families, either by increasing financial assistance (social tariff) or by making payments and debt collection more flexible (Ofwat, 2020).

Colombia is another outstanding international benchmark. The Colombian sectoral arrangement is similar to the Brazilian one, comprised of predominantly public service provision $-80 \%$ of the municipalities are served by public providers or by the municipality itself (Ministry of Cities, 2018). Colombian regulation, contrary to regulation in Brazil, has advanced a lot and is currently in its third phase of implementation. It relies on a national regulator that edits guidelines for local application (Center for Regulatory and Infrastructure Studies, 2018). With the pandemic, the Colombian government announced the provision of a minimum water volume for the residential population - six cubic meters - guaranteed by well-defined public financial resources.

The source definition of financial resources has not been noted in all Brazilian cases where tariff exemption has been granted. Some state governments assumed the payment of exempt users to reduce the impact on state companies. This is the case of Paraíba State (Sanitation Company of Paraíba State [Cagepa], 2020), Bahia State (Government of Bahia State, 2020) and Ceará State (Sanitation Company of Ceará State [Cagece], 2020). In other cases, such as the São Paulo's Company (Sabesp), the company will bear the cost which should be compensated by the reduction of expenses and budget adjustments (Sabesp, 2020).

Although the measures to protect users are meritorious during the pandemic crisis, their possible impacts in the medium and long term must be considered. The tariff exemption, as well as the concession of other benefits - for example, extended deadlines for tariff payment and the suspension of the collection of interest and fines - will unbalance the accounts of the service providers until the regulator starts the process of economic-financial rebalancing, which may only happen at the end of the period of social distancing.

\section{POTENTIAL IMPACTS AND CHALLENGES OF THE ADOPTED MEASURES}

This section discusses the potential impacts caused by social distancing and the actions taken by the Public Administration in terms of WSS on (i) service providers; (ii) users; and (iii) regulators, in the short, medium and long terms. In this section, we also propose approaches to Public Administration to mitigate some of the negative impacts of the preventive actions adopted.

\subsection{Service Providers}

Two of the effects of social distancing measures directly impact sanitation service providers. The first is the economic slowdown and the consequent increase in the level of unemployment; the second is the extended period of the population staying in their homes. As a consequence of the higher unemployment rate, an increase in the non-payment rate of users is expected, whose national average in the year 2018 (pre-pandemic) amounted to 6.5\% (MDR, 2018). Although the payment easing provided by some companies may soften the increase in non-payment, such measures were not adopted on a large scale by the SCs - only $15 \%$-, according to Figure 2. The suspension of procedures against non-payment may encourage users not to pay their bills, which will have a more significant impact 
than the eventual payment easing measures, since this was adopted on a much larger scale among state companies (88\%).

Changes in the pattern of water consumption are presumable due to two reasons: (i) population are staying in their homes; and (ii) commercial and industrial activities decreased. So, a reduction in water consumption by non-residential users (commercial, industrial, and public) and an increase in residential consumption are expected. This will have a negative impact on the companies' collection because of their tariff structure. For example, according to information made available via communication with a specialist from the São Paulo Regulatory Agency (ARSESP), the nonresidential economies of Sabesp, the largest sanitation company in Brazil, represent only 8\% of the total. In terms of measured volume, this representation increases to approximately $15 \%$. When participation in billing is added, it rises to $28 \%$, which proves the relevance of this category in the service providers' collection. So far, there is no official information available regarding the increase or reduction in demand of each user category; therefore, it is not yet possible to estimate the impact on the company's revenue resulting from the change in water consumption pattern.

Postponement of tariff readjustment, tariff exemption, suspension of fines, and extension of the deadline for paying tariffs are other measures to maintain service provision. All of them imply a reduction in service providers' cash flow entries. We detail social tariff exemption as it is the measure highly adopted by SCs (62\%). The social tariff creates an arrangement in which the user in the social category is subsidized and, therefore, bears a lower cost than he/she represents to the service provider. The social tariff is a benefit granted to the low-income population (social category). From the financial-economic perspective, the impact is lower on other users' categories when the social tariff is adopted than when low-income users do not need to pay any tariff. The latter case means that non-social-category users will divide the total costs of the exempted users (social category ones) among themselves and not only subsidize them.

Many of the service providers have chosen to migrate from the social tariff (subsidy) arrangement to a tariff exemption in response to the challenges posed by the pandemic. The representativeness of the economies that benefit from social tariff varies substantially among service providers: from over $14 \%$, in the case of Copasa, to about 1\%, in the case of Sanitation Company of Santa Catarina State (Casan), as indicated by the Brazilian Association of Regulatory Agencies (ABAR, 2018). This variation is justified, in part, by the different criteria adopted by the service providers in granting social benefits to users. Consequently, the collection via social tariffs also varies in terms of representativeness in the operating water revenues of SCs: it accounts for 9.5\% in Copasa, while in Casan, it accounts for less than $0.5 \%$ (ABAR, 2018). These data suggest that the financial and economic impacts of adopting this measure may vary greatly depending on the SC.

At the same time that the pandemic and its repercussions negatively impact the providers' revenues, its operating costs are either maintained or increased because of the extra expenses arising from the pandemic, such as the purchase of protective equipment for employees (e.g. masks, and alcohol gel). It is likely that the negative impact resulting from increased operating costs will not be of the same magnitude as that caused by reduced revenues. In any case, it seems that there will be an economic-financial imbalance among service providers. So far, there is no public data available to quantify the impacts. 
However, the SCs adopted some measures, as a result of the pandemic, that have the potential to reduce operational costs, if they are sustained after this period. One of these measures is the suspension or restriction of presential services and the consequent availability of virtual channels for users. It is not possible to state whether this will occur; however, one can imagine that if presential services are reduced, the rental expenses will decrease and, potentially, labor as well. This is a decision the SCs and the regulators will have to consider, especially in a post-pandemic context, which will still require, in the gradual return to "normal," some measures of social distancing until the population is immunized, and in which users will still live with reduced payment capacity. In this case, attention must be given so that the service maintains its quality even with the changes implemented.

Another opportunity for cost reduction comes from alternative billing measures, such as that adopted by Copasa, where the user himself communicates his water consumption to the service provider. In this case, if the measure is sustained after the pandemic, there will be a potential reduction in labor costs, as the current number of meter readers will probably no longer be necessary. However, this function goes beyond only reading the hydrometers because these employees also check equipment compliance, something the user cannot do.

Quantifying the economic-financial imbalance of the service providers is of fundamental importance so that the balance can be re-established when companies have their tariffs revised. Before that, in the short term, this quantification will allow identification of how long the working capital of the providers will be able to sustain their operations. So far, no studies have been published on the subject. Only once the impacts are identified will providers be able to claim for the re-establishment of their economic-financial balance.

We cannot assume that the negative impacts on service providers will cease once the rebalancing processes begin. This is because a new challenge will arise from judging the imbalances that were actually caused by the pandemic. At this point, there will be room for regulators to act with discretion in their decision-making. In reality, there is a risk of unpredictability in decision-making, when we consider this exceptional situation, as well as the absence of methodologies that enable a standardized treatment to calculate the impacts caused by the pandemic.

The lack of standardized methodologies predates the pandemic and affects the regulation of the Brazilian sanitation sector, which is fragmented because municipalities are responsible for sanitation services (Smiderle et al., 2020). As a reflex of regulatory fragmentation, regulators may act in different ways. Since the reform of the sanitation legal framework was recently sanctioned, establishing Law No. 14,026/2020, it is possible that some national guidelines will be issued on how to deal with the rebalances claimed in the context of a pandemic. The National Water and Sanitation Agency (ANA) will act as a regulatory supervisor, having the responsibility to edit reference standards to be followed by regulators.

\subsection{Users}

In the short term, all measures adopted by the Public Administration benefit the population, not only for the financial tranquility provided to users, especially the most vulnerable, but mainly for ensuring access to drinking water, thus contributing to the protection against COVID-19. In the medium and long term, however, these benefits become doubtful. On the one hand, once the right of 
economic-financial rebalancing is granted to the providers, the water and sewage tariffs will potentially increase, as the primary way to finance the service is by tariffs. On the other hand, citizens will have to pay, via taxes, the tariff exemption that, in some cases, was taken on by the respective state governments. This is the case of states such as Bahia, Ceará, Mato Grosso do Sul, and Paraíba.

We highlight two effects of state government subsidies grants. First, given the speed the Public Administration had to respond to the challenges imposed by the pandemic, one can infer that there was probably no provision in the Annual Budget Law for the commitment of public financial resources in the granting of these subsidies. In practice, what may happen is the reallocation of resources and the lack of financial coverage of some agenda. The second effect is that, as taxpayers are the ones who at some point will bear this tariff exemption, it is possible that a citizen paying tax is financing a subsidy, when he/she may not be benefited by access to water. Unfortunately, we must consider this situation, given the existing deficit that still exists in the sanitation sector in Brazil.

\subsection{Regulators}

In the administrative field, the regulatory fee charged to service providers ensures the financial sustainability of regulatory agencies. This fee is usually calculated as a percentage of the company's revenue from providing the services. It is, therefore, reasonable to assume that the expected drop in the service providers' revenues will negatively affect the collection of the regulatory agencies, as in a cascading effect. Therefore, the regulatory agencies will have to foresee how to deal with the reduction in revenue.

As mentioned, regulators will have to restore the economic-financial balance of service providers as a result of the measures adopted to combat the pandemic. The first challenge lies in interpreting the cause of this imbalance since this is a situation never faced before. The Attorney General of the Union (AGU) issued an opinion recognizing the right of transport infrastructure concessionaires to redress the balance of their contracts by characterizing the pandemic as a "force majeure" event ("fortuitous event") (Ministry of Infrastructure's Legal Consultancy, 2020). The reason for this interpretation was that service providers could not have foreseen the event and its consequences. If this same understanding is adopted for the sanitation sector, and there is a risk matrix defined in a contract that allocates the risk of force majeure to the granting power (municipalities), then the role of the regulator will be to guarantee the right of the provider to rebalance the accounts. In cases where there is no clear allocation of this risk, the regulator will have to act as a leader in conducting negotiations between the parties. In both cases, signing an additional contractual term to validate the decision will be essential, whether it is a tariff increase or, as alternative ways to avoid that, such as an extension of the contractual term or even an extension of investments.

The pandemic situation requires clear procedures due to the severity of its impacts. For this reason, regulators should clearly define the procedure that providers should follow to claim the economic-financial rebalancing caused by the pandemic. For example, regulators may require that the claim be accompanied by a public calamity declaration by the Executive Branch. Regulators will need to establish guidelines, norms, or even mediate the signature of an additional contractual term between the granting power and the provider. Such guidelines will have to answer common questions that will naturally arise from the providers. Issues such as: Can investments be 
extended? How can the quality of service provision be maintained with reduced revenue? How will non-conformities be dealt with?

At this time, the recommendation is that regulators should be cautious when overseeing the fulfillment of contractual investment targets. Due to the social distancing measures, some works may have been paralyzed, and regulators have to be aware of any such situations. If that occurs, regulators may consider making some goals more flexible. For investments, regulators could realign incentives and redefine priorities. We recommend that regulators conduct a regulatory impact analysis at an emergency pace before issuing any guidelines. By emergency pace, we mean a more agile process than usual, with instant data collection and rapid analysis.

While rebalancing processes have not began, regulators should make an effort to clearly define their procedures and listen to the granting authority and providers. Also, it is essential that regulators regularly request information from service providers on reducing or increasing water demand in the various consumption categories, as well as on input prices, so that any oscillation in values can be correlated to the effects of the pandemic. Regulators should also monitor whether there are paralyzed works. If there are, they should identify the reason for the interruption and be realistic about the feasibility of the resumption of the work in the short and medium-term.

\section{CONCLUDING REMARKS}

According to WHO guidance during this pandemic period, it is essential to guarantee the population has access to drinking water as a form of COVID-19 prevention. Service providers faced the challenge of maintaining their services for a population affected by an economic downturn and, therefore, unable to pay for the services. In this context, the players in the sector (municipalities, service providers and regulators) have taken actions to protect their employees and users, especially the most economically vulnerable. For the protection of employees, the measure preferred by state companies was the restriction of presential service in the service units, adopted by $88 \%$ of the states. Regarding the financial protection of the user, the most employed measures were the suspension of procedures against no-payment (88\%), followed by the exemption of the social tariff (62\%).

As per service providers, the short-term impact is the economic-financial imbalance of their accounts due to the benefits granted to the population, such as tariff exemption, suspension of the collection of fines, and the extension of the deadline for paying the tariffs. This situation is aggravated by increased costs due to the purchasing of protective equipment for employees and a change in water consumption pattern - reduction in demand from non-residential users. Service providers will

have to bear this imbalance in their accounts until the regulatory entity completes the rebalancing process, which should only occur after the pandemic period. Each service provider is responsible for quantifying the real impacts of the pandemic and the measures associated with it so that it can make its claim to the regulator.

The account will fall on users after the pandemic since water and sewage tariffs will potentially increase as a result of service providers' economic-financial rebalancing processes. Furthermore, in states whose governments have taken responsibility for the tariff exemption granted to vulnerable users, the contributing users themselves will, at some point, have to replenish the public resources reallocated at the time of the pandemic. 
RAP | The Brazilian sanitation sector's response to COVID-19

Regulators will face a great challenge of remedying the impacts caused to the service provider. Regulators will be an essential actor after this period, as it is during the pandemic. That is the reason this paper presents recommendations for them. Regulatory entities must clearly define its procedures so that service providers know how to claim their economic and financial rebalancing. We recommend that regulators issue guidelines and possibly firm additional terms that provide for the flexibility of contractual goals.

The relationship between regulators and service providers will be more important than ever at this time. These relationships will reduce the natural asymmetry of information between the parties and allow more transparency about what impacts on the cash flow of companies are associated, or not, with the pandemic. Good governance may minimize future implications for Brazilian citizens, both service users and taxpayers. 


\section{REFERENCES}

Brazilian Association of Regulatory Agencies. (2018). Tarifa Social nas companhias estaduais de saneamento básico e o papel da regulação. Brasília, DF: Author. Retrieved from http://abar.org.br/wpcontent/uploads/2018/12/3.-Estudo-Tarifa-SocialABAR-19-12.pdf

Center for Regulatory and Infrastructure Studies. (2018). Regulação e infraestrutura em busca de uma nova arquitetura. Rio de Janeiro, RJ: Author. Retrieved from https://ceri.fgv.br/sites/ default/files/publicacoes/2018-10/63_63_regulacaoe-infraestrutura-em-busca-de-uma-novaarquitetura-2018.pdf

Decreto Estadual n. 46,990, de 24 de março de 2020. (2020). Dispõe sobre a suspensão do faturamento de água e esgoto da CEDAE e dá outras providências. Retrieved from https://pge.rj.gov.br/comum/code/ MostrarArquivo.php?C=MTAyMzY\%2C

Deliberação ARSESP n. 978, de 8 de abril de 2020. (2020). Posterga a aplicação dos novos valores das tarifas de água e esgoto, resultantes da Segunda Revisão Tarifária Ordinária da concessionária Saneaqua Mairinque S/A. Retrieved from http:// www.arsesp.sp.gov.br/Legislacao Arquivos/ ldl9782020.pdf

Deliberação ARSESP n. 979, de 9 de abril de 2020. (2020). Autoriza a Companhia de Saneamento Básico do Estado de São Paulo - SABESP a adotar as medidas de que trata o artigo $5^{\circ}$, inciso II, do Decreto $\mathrm{n}^{\circ} 64.879$, de 20 de março de 2020, a fim de mitigar as consequências econômicas da pandemia da Covid-19, causada pelo Novo Coronavírus (SARS - CoV-2). Retrieved from http://www.arsesp.sp.gov. br/LegislacaoArquivos/ld19792020.pdf

Government of Amazonas State. (2020). Deputados aprovam lei sugerida pela Defensoria que proíbe aumento de preços e cortes de energia e água durante pandemia. Manaus, AM: Auhor. Retrieved from http://www.amazonas.am.gov.br/2020/03/ deputados-aprovam-lei-sugerida-pela-defensoriaque-proibe-aumento-de-precos-e-cortes-deenergia-e-agua-durante-pandemia/

Government of Bahia State. (2020). Sancionado PL que isenta inscritos na Tarifa Social de pagar conta de água por três meses. News. Salvador, BA: Author. Retrieved from http://www.bahia.ba.gov.br/noticias/ sancionado-pl-que-isenta-inscritos-na-tarifa-socialde-pagar-conta-de-agua-por-tres-meses

Government of Goiás State. (2020). Caiado garante que Saneago não cortará a água de quem atrasar pagamento. News. Goiânia, GO: Author. Retrieved from https://www.goias.gov.br/index.php/ servico/95-covid-19/121020-caiado-garante-quea-saneago-nao-cortara-a-agua-de-quem-atrasarpagamento

Government of Santa Catarina State. (2020). Enfrentamento ao coronavírus, ações do governo do estado de Santa Catarina. Florianópolis, RS: Author. Retrieved from http://www.coronavirus. sc.gov.br/wp-content/uploads/2020/04/ACOES-DEGOVERNO-30-DIAS-CORONAVIRUS.pdf

Government of Sergipe State. (2020). Belivaldo suspende cobrança de tarifa social da Deso beneficiando 40 mil sergipanos. Aracaju, SE: Author. Retrieved from https://www.se.gov.br/noticias/ governo/belivaldo_suspende_cobranca_de_tarifa_ social_da_deso_beneficiando_40_mil_sergipanos

Iguá Saneamento. (2020). Iguá suspende a cobrança da tarifa social. Retrieved from https://www.iguasa. com.br/noticias/igua-suspende-a-cobranca-datarifa-social

Ministry of Cities (2018). Publicação VI: Consultoria para ações de assistência técnica, elaboração de estudos e capacitação técnica em regulação e fiscalização de serviços de abastecimento de água e esgotamento sanitário (Projeto Regulação em Saneamento Básico - Regulasan). Brasília, DF: Author. Retrieved from https://www.integracao.gov.br/images/ stories/ArquivosSNSA/regulasan/11Publicacaovi PropostaDeProgramaseAcoes Estrategicas No AmbitoDe Subsidio.pdf

Ministry of Infrastructure's Legal Consultancy. (2020). Parecer n. 261/2020/CONJUR-MINFRA/ CGU/AGU. Consulta em tese. Covid-19. Reequilíbrio de contratos de concessão. Força Maior. Consultoria Jurídica Junto Ao Ministério da Infraestrutura Gabinete da Consultoria Jurídica. Brasília, DF: Felipe Nogueira Fernandes. Retrieved from https://sapiens. agu.gov.br/documento/406894540

Ministry of Regional Development. (2018). Base de Dados do Sistema Nacional de Informações sobre Saneamento - Séries Históricas. Brasília, DF: Author. 
NH Consulting and Planning. (1995). Regulação da prestação de serviços de saneamento: análise comparada da legislação internacional (Série Modernização do Setor Saneamento, 6). Brasília, DF: IPEA.

Office of Water. (2020). Letter to all CEOs from Rachel Fletcher on COVID19 water industry response. Londres, UK: Author. Retrieved from https://www. ofwat.gov.uk/wp-content/uploads/2020/03/Letterto-all-CEOs-from-Rachel-Fletcher-on-COVID19water-industry-response.pdf

Regulatory Agency of Paraná State. (2020). Estado congela por 60 dias tarifas dos serviços regulados. News. Curitiba, PR: Author. Retrieved from http:// www.agepar.pr.gov.br/modules/noticias/article. php? storyid=256\&tit=Estado-congela-por-60-diastarifas-dos-servicos-regulados

Resolução ADASA n. 03, de 26 de março de 2020. (2020). Dispõe sobre o adiamento do Reajuste Tarifário Anual - RTA da Caesb para $1^{\circ}$ de outubro de 2020 e dá outras providências. Brasília, DF: Diário da União. Retrieved from http://www.adasa.df.gov. br/images/storage/legislacao/Res_ADASA/2020/ Resolucao_03_2020.pdf

Resolução ARES-PCJ n. 345, de 23 de março de 2020. (2020). Dispõe sobre as Condições Gerais de Prestação dos Serviços Públicos de Abastecimento de Água Tratada e de Esgotamento Sanitário, no âmbito dos municípios associados à Agência Reguladora PCJ, durante o período de excepcionalidade, emergencial e atípico, para enfrentamento da pandemia de COVID-19, e dá outras providências. Retrieved from http://www.arespcj.com.br/arquivos/ 63909_Resolu\%C3\%A7\%C3\%A3o_n\%C2\%BA_ 345_2020_-_Condi\%C3\%A7\%C3\%B5es_Gerais_-Pandemia_de_COVID-19.pdf

Rondônia State Public Services Regulatory Agency. (2020). Agero adverte: empresas concessionárias não podem interromper o fornecimento de água durante 60 dias. News. Porto Velho. Retrieved from http:// www.rondonia.ro.gov.br/agero-adverte-empresasconcessionarias-nao-podem-interromper-ofornecimento-de-agua-durante-60-dias/

Sanitation Company of Ceará State. (2020). Famílias beneficiadas: isenção nas contas de água garante serviço essencial durante a pandemia. News. Fortaleza, CE: Author. Retrieved from https://www. cagece.com.br/comunicacao/noticias/familiasbeneficiadas-isencao-nas-contas-de-agua-garanteservico-essencial-durante-a-pandemia/

Sanitation Company of Espírito Santo State. (2020). Cesan concede isenção do pagamento das contas de água para 25 mil famílias no Espírito Santo. News. Vitória, ES: Author. Retrieved from https://www. cesan.com.br/noticias/cesan-concede-isencaodo-pagamento-das-contas-de-agua-para-25-milfamilias-no-espirito-santo/

Sanitation Company of Minas Gerais State. (2020a). Release de 23 de março de 2020: Prevenção Coronavírus - Saiba como a Copasa está atuando. News - Release. Belo Horizonte, MG: Author.

Sanitation Company of Minas Gerais State. (2020b). Release de 6 de abril de 2020: Prevenção Coronavírus - Orientações para atendimento. News - Release. Belo Horizonte, MG: Author.

Sanitation Company of Paraíba State. (2020). Clientes da tarifa social estão isentos de pagamento das contas até junho. News. João Pessoa. Retrieved from http:// www.cagepa.pb.gov.br/mais-de-25-mil-familiasnao-pagarao-conta-de-agua-a-cagepa-ate-o-mesde-junho/

Sanitation Company of Paraná State. (2020). Fato Relevante de 23 de março de 2020. Curitiba, PR: Author. Retrieved from http://ri.sanepar.com.br/ ptb/2306/18627_747418.pdf

Sanitation Company of Rio de Janeiro State. (2020). Fato relevante do dia 26 de março de 2020. Rio de Janeiro, RJ: Author. Retrieved from https://www. cedae.com.br/Portals/0/ri_cedae/comunicados/ fato_relevante/Fato\%20Relevante_20200326.pdf

Sanitation Company of Rio Grande do Norte State. (2020). Caern esclarece que suspensão de cobrança é só da tarifa social. News. Natal. Retrieved from http://portal.caern.com.br/Conteudo. asp? TRAN $=$ ITEM \&TARG $=227980 \& A C T=\&$ $\mathrm{PAGE}=\& \mathrm{PARM}=\& \mathrm{LBL}=\mathrm{NOT} \% \mathrm{CDCIA}$

Sanitation Company of Rio Grande do Sul State. (2020). Comunicação do dia 01 de abril de 2020: Companhia adota medidas para minimizar impactos da pandemia no Estado. Porto Alegre. Retrieved from https://www.corsan.com.br/companhia-adotamedidas-para-minimizar-impactos-da-pandemiano-estado 
Sanitation Company of São Paulo State. (2020). Fato Relevante de 19 de março de 2020. São Paulo, SP: Author. Retrieved from http:// www.sabesp.com.br/CalandraWeb/Calandra Redirect $/$ ? temp $=4 \&$ proj=investidoresnovo $\& \mathrm{pub}=\mathrm{T} \& \mathrm{par}=\mathrm{rel} \& \mathrm{db}=\& \mathrm{docid} \mathrm{Pai}=\mathrm{F} 8 \mathrm{C} 240$ A 5 E 71426 D F 8325768 C 0051 B F F F \& d o cid=77644B66786E7BAF03258531000A2E13

Smiderle, J., Capodeferro, M., Fernandes, P., Gonçalves, E., \& Dutra, J. (2020). The governance of water and wastewater provision in Brazil: are there clear goals? Network Industries Quarterly, 22(1), 7-11.

Tocantins State Sanitation Agency. (2020). Governador determina suspensão de cortes de água e energia. News. Palmas, TO: Author. Retrieved from https://ats.to.gov.br/noticia/2020/3/25/ governador-determina-suspensao-de-cortes-deagua-e-energia-/

United Nations Children's Fund and the World Health Organization. (2019). Progress on household drinking water, sanitation and hygiene 2000-2017.
Special focus on inequalities. New York, NY: United Nations Children's Fund (UNICEF) and World Health Organization (WHO). Retrieved from https://washdata.org/report/jmp-2019-washhouseholds

World Health Organization. (2020). Responding to community spread of COVID-19 - Interim Guidance. Retrieved from https://apps.who.int/iris/rest/ bitstreams/1271989/retrieve.

Wu, Y., Guo, C., Tang, L., Hong, Z., Zhou, J., Dong, X., ... Huang, X. (2020). Prolonged presence of SARS-CoV-2 viral RNA in faecal samples. The Lancet Gastroenterology \& Hepatology, 5(5), 434435. Retrieved from https://doi.org/10.1016/S24681253(20)30083-2

Yeo, C., Kaushal, S., \& Yeo, D. (2020). Enteric involvement of coronaviruses: is faecal-oral transmission of SARS-CoV-2 possible? The Lancet Gastroenterology \& Hepatology, 5(4), 335-337. Retrieved from https://doi.org/10.1016/S24681253(20)30048-0

\section{Morganna Werneck Capodeferro}

https://orcid.org/0000-0002-5617-5673

Researcher at the Center for Regulatory and Infrastructure Studies of Fundação Getulio Vargas (FGV CERI); Master's student in Civil Engineering in the Civil Engineering Program (PEC/COPPE) at the Federal University of Rio de Janeiro (UFRJ).E-mail: morganna@poli.ufrj.br

\section{Juliana Jerônimo Smiderle}

https://orcid.org/0000-0003-3319-7359

Researcher at the Center for Regulatory and Infrastructure Studies of Fundação Getulio Vargas (FGV CERI); Master's student in Environmental Engineering in the Environmental Engineering Program (PEA) at the Federal University of Rio de Janeiro (UFRJ). E-mail: julianasmiderle@poli.ufrj.br 